\title{
Transformation of baliseering into ajeg bali: Comodification of bali in exotic tourism industry
}

\author{
I Made Pageh ${ }^{1}$; Ketut Sedana Arta $^{2}$, dan I Wayan Pardi ${ }^{3}$ \\ \{made.pageh@undiksha.ac.id ${ }^{1}$ \} \\ Universitas Pendidikan Ganesha, Indonesia ${ }^{1,2,3}$
}

\begin{abstract}
This study aims to: (1) understand the commodity of the tourism industry on Baliseering and Ajeg Bali Program; (2) analyze the transformation that occurred in the commodification of Bali. The current research refered to Historical Method with the following steps: heuristics (data collection), source criticism (validity of data sources), interpretation (interpereting data into facts), and historiography (in a critical perspective). The results showed that there is a relationship between The Baliseering Program and Ajeg Bali Movement, namely there is a transformation of the zeitgeist to comercialize the exotic Balinese culture. The exotic culture of Bali was preserved as a cultural tourism commodity by the Dutch government, while in the post-colonial times Bali was totally comfified, not only its exotic culture but also land, customs, and religious system. The ideological conflicts among the Balinese people are continuously used as the background of this commodification of Bali. Continuous capitalism (mimicry) occupied a special position in these two movements. The discourse Baliseering and Ajeg Bali are seen as counterproductive discourse taking the account of zeitgeist and cultuurgebudenheit (the spirit of the times and the cultural ties of the times). However, as the investors and authorities have an interest on it, the tourism industry can be implemented and justified.
\end{abstract}

Keyword: Baliseering; Ajeg Bali; Cultural transformation.

\section{Introduction}

The promising potential of the Bali tourism industry prompted the Dutch colonial government to issue a Baliseering Policy. The policy aimed to preserve Bali, making it a living museum. To protect Bali from outside influences, the Dutch even cenceled the plantation project on West Bali [1] and blocked the progress of the Balinese society, lead by Balinase educated groups. The reformists were labld as "red movement" with a communist ideology, which was a "ghost for western capitalism" at that time.

The idea of Baliseering was initiated by H. Te Flierhaar, a school supervisor in Klungkung. His article entitled "De Aan passing het Inlandsche Onderwijs op Bali Aan de Eigen Sfeer" published in 1931 in Batavia became the basis for the Baliseering Policy of the Dutch colonial government to promote Bali in order to attract tourists [2].

The history of Baliseering policy repeated itself marked by the emergence of the Ajeg Bali Movement in 2002[3]. This program is aimed at preserving Balinese culture. Ajeg Bali was 
originally a form of resistance against terrorists who boombed Bali. It is interesting to note the transformation that occurred on the reemergence of Baliseering Policy on Ajeg Bali Program[4].

The writings about Bali are needed in this study, such as 'Bali' [5], 'Island of Bali' [6], 'Spell of Power: A History of Balinese Politics, 1650-1940' b'Bali: Culture Tourism and Tourism Culture' [8]. A Literary Mirror: Balinese Reflection on Modernity and Identity in The Tweentieth Century and a collection of essays edited by Nyoman Darma Putra and I Gde Pitana Bali, in the National Character Building Process[9], Bali Tempo Doeloe [10], The Dark Side of the Island of the Gods: A History of Political Violence [11] [12]. Discussed the importance of the Baliseering Policy in providing the pondation for the development of Balinese cultural tourism. [12] examined "Baliseering Genealogy: Unraveling the Ideology of Colonial Education in North Bali and Its Implications in the Era of Globalization", Dissertation, Udayana University Denpasar. The writing explains materialistic, secular, and hegemonic ideologies included in Balinese structure and culture, found on the production of wall reliefs, placement of clocks in Catus Pata (center of the four junction road), existence vehicle reliefs at Dalem Jagaraga Temple, and naked Balinase female used as promotion tools.

Ajeg Bali according to [14]is a utopian power construction, non ideological and paradoxical. Unmistakably, Ajeg Bali has trigered conflicts caused by arrogance presented by the local security grup and Pacelang in Bali. Ajeg Bali is a responsive ideological construction that serves as a security wall against terrorist and foreign capital. Eventhough, the authorities continues to construct and promote touristic culture, not cultural tourism ([8], foreign investors still commits ideological violations that make Balinese people become foreigners in their own land.

Geria [15] explains cultural transformation as a cultural concept that opposes linear concept by looking at the continuity and discontinuity of culture that occurs. Structurally functional cultural dynamics occur in three cultural forms, namely: (1) ideas, thoughts, ideals, and norms; (2) Socio-cultural system; (3) Artifacts, in the form of existing objects. Transformation sees culture changes in form/structure, function and meaning, along with the times. The authorities and investors have an interest in preserving or revitalizing the old cultural system for thier own interests to maintain their existence.

Based on the above background, the purpose of this research is (1) understanding the idea of Baliseering Policy and the ideology of the Ajeg Bali Movement; (2) understanding the ideology transformation of the Baliseering Policy on the Ajeg Bali Movement.

\section{Method}

The study used a historical writing procedure, with the following steps: (a) Heuristics, the study begins with the search for sources, both contemporary and non-contemporary, such as documents, newspapers, bulletin, monthly magazines, artifacts, books, and photos in the time of the implementation of Baliseering Policy (1919-1942)[13]. (b) Source Criticism, the sources that were collected then read, criticized, legally tested, and compared, so that the source could be trusted. (c) Interpretation, interpreting the data into a discourse (cultural history facts). (d) Writing an article. The social science perspective applied is economics by examining the basic factors of the tourism industry during the Baliseering and Ajeg Bali era. As the event expnded from pre-independence to post-independence, the concept of mimicry, hybridization and oppresion are included. Political economy theory and postcolonial criticism discussed by theorists, such as Gramsci, Edward Said, Gayatri Cakravorty Spivak, Frans Fanon, and Homi $\mathrm{K}$. Bhabha were used in the analysis process. 
Critical history methodology employed critical theory in building facts to produce critical postcolonial historical stories. It can be found on the work of Edward Said with his theory of Orientalism (1978). It can also be found on the view of Lubis (2006) that states the essence of sublimated culture and politics in the west-east dichotomy and the subordination of west to east, a plurality views is needed. Sipivak highlighted the oppressed subaltern women. Historical and social writings only place men and authorities as dominant voices. It requires counter cultur and bigger attention to gender in the globalization era [16]. Fanon highlighted the identity, race, and ethnicity, especially looking at the black race that psychologically was under tremendous pressure, as a result of being the object of suffering of the western domination [16]. Homi K. Bhabha with the concept of mimicry and hybridization explains the mix of post-colonial culture, especially in the analysis of cultural forms in the form of ideas, thoughts, cultural behavior, and remaining artifacts.

\section{Result and Discussion}

\section{Caste Conflict a Gateway to Baliseering}

Baliseering Policy introduced the ideology of Balinization through education, by adapting the Balinese culture to the education system. HIS School in Kelungkung changed its curriculum in 1930. The change was in drawing subject by recruiting "traditional teachers", graduated from teacher courses (MULO). The main policies of Baliseering were stated by Flierhaar (1931 on [13]): School building in Bali must be built according to Balinase style; Changing the form of drawing subject; Changing the form of singing subject; Collecting reading material for making books; Incorporate elements of Balinese dance into sports education [13].

The Balisering Policy was also followed by blocking cristian missionaries, Lekkerkerker wrote about the opposition between the Zending and Western orientalists in the Tijdschrift Colonial, related to the prohibition of Zending and Christian Missionaries [13], and oppresing modernist group by accusing them of being the "Red Movement, having a comonist ideology". The modernist group was said to threaten the great Balinase civilization on the justification that Bali was a remnant of $15^{\text {th }}$ century Hindu civilization. This letter became the root of caste conflict in Bali, between Triwangsa (nobel) group and the modern educated Jaba (lay people)

The conflict was marked by the publication of Surya Kanta and Bali Adnyana magazine. The Bali Adnyana magazine, first published oEn January $1^{\text {st }}, 1924$ [17]represented the idea of artodochism. I Gusti Tjakaratanaya, triwangsa key figure, argued that caste and the Tirta religion was originating from Java. The article prompted Wangsa Jaba to react because they were said damaging Balinese tradition. Wangsa Jaba responded by establishing the Surya Kanta Association publishing Surya Kanta Magazine. The key figures of the Surya Kanta were Ketut Sandi (official of Singaraja), Nengah Merta (teacher), Ketut Nasa (teacher). Surya Kanta Association and the Surya Kanta Magazine were established on November 1, 1925, [18].

The Jaba group aimed at empowering poor farmers because of market economy brought by western modernism, the rapid development of the population, and the spread of influenza virus. Some ideas of the educated elite that failed to spread were (1) fostering community economic awareness through cooperation and (2) spreading ideas of efficient Pengabenan ceremonies, especially the Ngaben tradition, [18]).

The Dutch though that the ideas of modernity unfavorable for their political interests. Caste conflict used to silence the Jaba wangsa group, the educated elite, and the idea of a national revival (Bhudi Utomo). Theoretically, both the conservative and the progressive groups have a 
plausible basic argument. However, Tri Wangsa Grup prevailed because of the power behind the reproduction of truth [19].

\section{Bali as the Tourism Industry: Commodification of Bali}

The Dutch power orientation was to manipulate Bali into a "dollar machine" or "smokeless factory" for cultural tourism, while the effect was that Bali became a consumptive tourism culture (cf. [8]). To protect Bali from outside influences, the Dutch government issued a protective policy to block the influence of capitalism, nationalism, communism, and modernism, so that Bali remains untouched and it become living museum of traditional cultural with its premitive image. Politically, the Dutch government was isolating Bali from the nationalist movement from Java, developing anti-Javanese Islamic sentiment and Javanese influence to Bali which happed since the the time great Kingdom of Mojopahit.

Preparations were also made by renovating the ancient temple, adding hegemonic reliefs in the most sacred temple such as reliefs of raping, airplanes, drinking beer, bicycles, etc. The Buddhist teachings that encourages self-controlled are ommited by showing exotic scenes at Dalem Sangsit Temple, Balingkan Bungkulan Temple, Beji Sangsit Temple, Maduwe Karang Temple Kubutambahan, and Segara Madu Jagaraga Temple [20]. Modern painting class was administered by the Pitamaha foundation under the guidance of Wolter Spisce and Arie Smith in Ubud. Its main objective was to prepare balinase artist to produce art works that can be sold to tourist. Classical painters were directed to modify their style to follow western style.Krause [5] printed hundreds of exotic picture about Bali (1920-1930s). Through KPM, Balinase culture such as Balinese dance, Balinese women with exposed breasts, traditional markets, cremation rituals, etc was introduces to western word.

Tourism industry factors greatly support the success of a tourism product, including: Bali with the concept of "nyegara-gunung" makes it rich in natural attraction and temples. The concept of "nyegara-gunung" is the basis of Balinese philosophy called the rwabhineda concept. It affects the land use in Bali. Land is divided into three areas, hulu or uppper areas (mountains), teben/lower areas (sea), and middle (plains) area specifically build for housing (called pawongan). This concept is called Trihita Karana, which is three harmonious relationships to create happiness consisting of human relations with God, humans with humans, and humans with the natural environment[20].

The distribution of temples in Bali is also based on this concept. Major temples were in mountainous areas and on beaches (Public Temples). Meanwhile, large temples in the middle area (Pawongan) are for worshiping ancestral spirits, such as Dadia, Kawitan, Merajan Agung and Swagina temples[21]. Subak as a production unit in a subsistence economy also contributed in creating the beauty of Bali [22]. The speciality of Subak is creating beautiful, stunning rice terraces that demonstrate crafmanship in constructing water dams, tunnel and waterways that stretch tens of kilometers. Foreigners see this rice terrace as a hanging garden, like a natural painting, with varying colors depending on what season the rice fields are seen. The beautiful scenery is supported by sophisticated culture, plowing the land using buffalo-pulled plow and traditional hoe, nambah / numbeg, nengala, ngelampit, melasah, ngabut bulih, backwards planting rice technique, catching the baby dragonflies (nyeser), mekukung, harvest rice with aniani, mutual cooperation of mebleseng, ritual of storing rice to the ricebarn.

Subak is a technician and manager in regulating water distribution and performing rituals related to the subak temple, Ulun Swi. The temple is related to the buka (dam) of the main water source. The subak organization existed in the 11th century, recorded in the Klungkung inscription, the Manukaya inscription, the Tengkulak inscription and the Bangli inscription. Subak is a Balinese supporting organization. Bali has three supporting pillars, namely Subak, 
Traditional Village, and Kingdom (feudalism). Subak with its rice fields, water, and rituals, Traditional Village as the implementer of Balinese tradition and customs, and the kingdom as the center of civilization, are important for Balinese life as a whole[22].

The male Balinese are portrayed as lazy, heavy gambler, and dependent, especially to their spouse. In the spare time after planting rice, male Balinase would entertaint themselves by mebombong (training fighting cook). Street cockfighting is called a branangan with a modest bet. Whereas cockfighting in the Tajen arena is carried out with clear norms, betting rules, the present of Tajen official (Saya), pakembar, and bebotoh[23]. That is the image of male Balinase. Lazy, gambler, and dependent image was consciously constructed by Dutch government to create the encient impression (living museum). Several photos of Balinase were use as promotion tool to Europe. To European, Balinese people look innocent and their eyes are exotic. Balinase also well know for their uniqueness, especially their dancing skills [24].

The Balinese artists produced amazing art works, dominated by classical arts such as wayang (puppet), masks, barong and other art works. Old Balinase did not commercialize their art work. They presented thier work as an offering to their gods. Art works at old time were mainly used as temple or holy places accessories, holy water containers decoration, pratima (god idols) and other temple related items. The cultural factor is capital asset of the cultural tourism. Balinese cultural tourism products are valuable items in the world tourism market. Exotic culture is the most interesting show because it is endemic in Bali. Baliseering introduce exotic cultural tourism, such as shrine, temple wall reliefs, as well as exotic Balinese nature and people.

\section{Ajeg Bali: Post-Collonial Commodification of Bali}

Balinese interpret Ajeg Bali as return to the origin, pure and peaceful Bali. Ajeg Bali offers Balinase an answer to an empty modernization [25]. The construction of Ajeg Bali coincided with the inauguration of Media Bali TV. At that time, Governor Beratha conveyed the vision and mission of Bali TV, namely "Developing and Promoting Balinese Customs and Culture".Bali Boombing turned the job market hard for Balinase. Thus, Balinase had to fight in another sector, namely the informal sector business. Unfortunatetly, non-Balinese ethnic groups dominated the informal business sector. It created the image of insecure Bali. So, Bali needed protection in the context of Balinese history, customs and culture. It emerges in the form of Pecalang and self-formed security[26].

Viewed from the socio-cultural transformation, the core conflict is actually a conflict of economic interests, represented on the Dangin Tukad and Dauh Tukad discourse. The conflict transformation that has been constructed since the Baliseering policy is based on the construction of Java as a Balinese colonizer from Mojopahitization to Islamization re-emerged in the discourse of Ajeg Bali. Pecalang is Balinese traditional guard [26]. Onother self-formed scurity are also exsist, such as: Lakar Bali, Baladika, Pemuda Bali Bersatu (PBB), and newly formed is Semeton Keris a split from Laskar Bali. They often engaged in brawl over security service [27].

The weak character of the Balinese people is due to the influence of tourism culture, capitalism, and hedonistic materialism resulted in the idea of guarding Balinese ethnic identity, through education and Balinese culture. Nordholt [7] stated that the Desa Pakraman (traditional village) identified themselves as the last defender of the island of Bali. Thus, Ajeg Bali is sinonimous to the Desa Pakraman. The Ajeg Bali movement transformatively brought Desa Pakraman to be dominative and hegemonic, which implies the emergence of disharmony in Balinese society psychologically, because the concept of penyamabrayaan (family unit) is now marginalized [28]. 


\section{Transformation of Baliseering to Ajeg Bali}

Ajeg Bali raises ethnocentrism which produces stereotivism against other ethnicities. This indication arises in connection with the migrants and their further impact. Referring to Sukarma (2009: 10), further impacts occur due to instability of spatial supporting capacity, decreasing ecological quality, uncontrolled population, tighter competition, denser social spaces, pseudosocial interaction and integration, wide social autonomy and cultural differentiation. Degung Santikarma said that migrants were often positioned as trouble makers who threaten both Balinese and their cultural identity. The migrant are said to destroy "identity" because they come from different customs background, cultures and beliefs, while the Balinese are the guardians of tradition and the purity of Hinduistic cultural identity [29]. When criminal cases reported, the perpetrators were quickly labeled as dauh tukad or dangin tukad people (non-Balinese), a sign of "war-ready culture" (armament culture). This indication is a marker of dissociative social processes that are not accordance with the concept of multiculturalism. The competition that occurs is fight over economic resources between Balinese and foreign ethnic groups in Bali[30][31]. This strategy is not only intended to differentiate itself from the opposing parties, but also to foster social solidarity among Balinese. In order to reach associative interactions (preventing dissociative interactions), the idea of accommodation must be developed (called hybridization and mimicry by K.Bhabha, in [16]), so that no one loses personality.

There is a transformation of the spirit and culture of Baliseering Policy into Ajeg Bali, it is excessive ethnocentrism and ethnic stereotypes. The results of the study are summarized in the following table.

Table 4.1 Transformasion of Baliseering on Ajeg Bali Movement

\begin{tabular}{lll}
\hline No. & \multicolumn{1}{c}{ Baliseering } & \multicolumn{1}{c}{ Ajeg Bali } \\
\hline $\mathbf{1}$ & $\begin{array}{l}\text { Caste conflict was constructed to stop the } \\
\text { educated modernity group. }\end{array}$ & $\begin{array}{l}\text { Ethnicity is constructed to builds resilience and } \\
\text { a sense of oppresed from other Ethnic "Dauh } \\
\text { Tukad and Dangin Tukad". }\end{array}$ \\
\hline $\mathbf{2}$ & $\begin{array}{l}\text { Capitalism turned exotic cultural as object } \\
\text { of tourism industry and disguised as } \\
\text { Baliseering (Conservation) }\end{array}$ & $\begin{array}{l}\text { Capitalism is protected from terrorist threat, the } \\
\text { protection of tourism objects as a product of } \\
\text { the tourism industry. }\end{array}$ \\
\hline $\mathbf{3}$ & $\begin{array}{l}\text { Caused by the criticism of Dutch violence } \\
\text { in Puputan-war in Bali (1906 Badung; } 1908 \\
\text { Klungkng). }\end{array}$ & $\begin{array}{l}\text { Triggered by Bali Bombings I and II (2002, } \\
\text { 2005). }\end{array}$ \\
\hline $\mathbf{4 .}$ & $\begin{array}{l}\text { Schools were used as a tool of Balinization } \\
\text { (Picard 2006). }\end{array}$ & $\begin{array}{l}\text { Pecelang and self-formed secutiry (Laskar Bali } \\
\text { and Baladika) are a mean of protecting the } \\
\text { safety of Bali. }\end{array}$ \\
\hline $\mathbf{5 .}$ & $\begin{array}{l}\text { The actor was Dutch Colonial with } \\
\text { Tourism bussines interests }\end{array}$ & $\begin{array}{l}\text { The actors were Balinese, initiated by the } \\
\text { Bali Post Media Group. }\end{array}$ \\
\hline
\end{tabular}

\section{The Contra Productive Indication of the Ajeg Bali}

Ajeg Bali raises two warning signs. First, the position of the Desa Pakraman based on Balinese culture and Hinduism is strengthening. Desa Pakraman has extensive authority, not only for custom and religious matter, but also security, people, and creating local regulation. Second, Pacelang has the right to make policies for migrants (minorities). Immigrants are accepting of all Desa Pakraman policies[29].

Hybridization and multicultural thinking are needed in developing the future of Balinese Cultural Tourism. Historically, Bali does not only have a Hindu background, but also Malay Austronesian, Islamic and Christian civilizations. By developing ideas of hybridization and multiculturalism, ethnic arrogance can be reduced in a country that based on The 1945 Constitution and Pancasila ideology as well as the agreement of the state founder. Historical 
accident is common in the history of mankind, by learning from history, Indonesia will become great country [32].

\section{Conclusion}

The conclusions of this paper are as follow: Baliseering and Ajeg Bali hide the motive of commodification of Balinese culture; the ideology of Balinese culture preservation program is spread massively through political and educational policies, so that exotic cultural tourism can be accepted by Balinase; and both of the movements are constructing inter-regional, local and national conflicts. The suggstions that can be given are the factors of Balinese cultural tourism industry, such as Balinese nature, Balinese people and Balinese civilization (customs, subak, and Hinduism / Hinduism) must be preserved. The lost of these factors will lead to the death of Balinese cultural tourism, various parties related to the factors in tourism industry must understand that Balinese cultural tourism has been strengthened during the Baliseering era, so that they can learn from the Baliseering of the Dutch colonial era, and Pacelang should not construct inter-ethnic enmity but build inter-ethnic fraternity with the concept of penyamabrayaan (Nyama Bali-Nyama Selam).

\section{References}

[1] I. M. Pageh, "Gerakan Protes Petani Berbasis Tanah di Sumberklampok Kecamatan Gerokgak, Kabupaten Buleleng Bali," Has. Penelitian. IKIP Negeri Singaraja, hal. 2001, 2001.

[2] I. M. Pageh, "Genealogi balinisasi zaman kolonial belanda: analisis kritis bali sebagai museum hidup," no. 2010, hal. 896-902, 2017.

[3] D. Miharja, "Adat, budaya dan agama lokal Studi Gerakan Ajeg Bali Agama Hindu Bali," Kalam, vol. 7, no. 1, hal. 53, Mar 2017, doi: 10.24042/klm.v7i1.444.

[4] N. K. Karuni dan I. W. Suardana, "Wacana 'Ajeg Bali’ Pada Seni Kerajinan Sarana Upacara Di Gianyar Bali," Mudra J. Seni Budaya, vol. 33, no. 1, hal. 26, Mar 2018, doi: 10.31091/mudra.v33i1.321.

[5] G. Krause, Bali 1912. Kum-Vivar Printing, 2001.

[6] M. Covarrubias, Pulau Bali Temuan yang menakjubkan (Sunaryo Basuki: Penerjemah). Denpasar: Udayana Press., 2012.

[7] H. S. Nordholt, Bali Benteng Terbuka 1995-2005: Otonomi Daerah, Demodrasi Elektroral, dan Identitas-/identitas defensive,. Singapore, 2007.

[8] M. Picard, "Cultural Heritage and Tourist Capital: Cultural Tourism in Bali," Int. Tour. Identity Chang., no. December, hal. 44-66, 2012, doi: 10.4135/9781446250402.n3.

[9] D. I. Nyoman, Metamorfose Identitas Bali Abad Ke-20 dan Kontribusinya dalam Pembentukan Kebudayaan Bangsa", dalam Darma Putra dan Pitana (ed), Bali dalam Proses Pembentukan Karakter Bangsa. Denpasar: Larasan, 2011.

[10] A. Vickers, Bali Tempo Doeloe (Kumpulan Karangan). Jakarta: Komunitas Bambu, 2012.

[11] G. Robinson, Sisi Gelap Pulau Dewata: Sejarah Kekerasan Politik. Yogyakarta: LKiS., 2006.

[12] I. M. Pageh, Desertasi : Genealogi Baliseering: Membongkar Ideologi Pendidikan Kolonial Belanda di Bali Utara dan Implikasinya di Era Globalisasi. tidak dipublikasikan, 2016.

[13] I. B. Sidemen, Balisering dan Perkembangan Pariwisata Budaya di Bali”. Denpasar: Laporan Hasil Penelitian . Universitas Udayana., 1983.

[14] A. Kumbara, Konstruksi Wacana Ajeg Bali dalam Relasi Kusa: Antara Ideologi dan Utopia”, 6 November., no. November. Orasi Ilmiah Pidato Pengenalan Guru Besar dalam Bidang Epistimologi Antropologi, Fakultas Sastra Universitas Udayana, 2010.

[15] I. W. Geria, Transformasi Kebudayaan Bali, Memasuki Abad XXI. Surabaya: Paramita, 2008. 
[16] N. Martono, Sosiologi Perubahan Sosial: Perspektif Klasik, Modern, Postmodern, dan Pascakolonial. Jakarta: Rajawali Pers, 2011.

[17] A. A. G. P. Agung, Peruubahan Sosial dan Pertentangan Kasta di Bali Utara. Yogyakarta: Yayasan Untuk Indonesia, 2001.

[18] S. Kanta, "Konflik Kasta," 1 Nov 1925, Singaraja, hal. 16, Nov-1925.

[19] P. 198 Bourdieu, The Form of Capital". Dalam Hand Book of Theory and Research for The Sociology of Education, New York. Green- wood Press, 1986.

[20] I. M. Pageh, "Kearifan Sistem Religi Lokal dalam Mengintegrasikan Umat Hindu-Islam di Bali," J. Sej. Citra Lekha, 2018, doi: 10.14710/jscl.v3i2.19411.

[21] I. M. Pageh dan I. W. P. Yasa, "The History of Taman Sari Temple in Sebudi Village, Selat, Karangasem, Bali and its Potential as a Tourist Attraction," 2020, doi: 10.2991/assehr.k.200115.027.

[22] W. Windia, S. Pusposutardjo, N. Sutawan, P. Sudira, dan S. S. Arief, "Transformasi Sistem Irigasi Subak yang Berlandaskan Konsep Tri Hita Karana," agritech, 2017, doi: 10.22146/AGRITECH.13519.

[23] N. T. Aryanata, "Budaya dan Perilaku Berjudi: Kasus Tajen Di Bali," J. Ilmu Perilaku, vol. 1, no. 1, hal. 11, Agu 2017, doi: 10.25077/jip.1.1.11-21.2017.

[24] E. Y. Yuval Noah Harari, Slavoj Zizek, Arunhati Roy, Ethan Siegel, Ross Douthat, Hendry Marsh, Santiago Zabala, Wabah, sains, dan politik, 1 ed. Yogyakarta: Yogyakarta: Penerbit Antinomi, 2020.

[25] H. S. Nordholt, Bali: Benteng Terbuka 1995-2005. Denpasar: Pustaka Larasan dan KITLV, 2010.

[26] N. N. J. Arsawati, "Pecalang Existence in Keeping Public Order and Safety of Pakraman on the Celebration of Nyepi in Bali," Int. Res. J. Manag. IT Soc. Sci., 2016, doi: 10.21744/irjmis.v3i9.167.

[27] K. A. S. Wijaya, "Laskar bali dan eksistensi di masyarakat bali," Universitas Udayana, 2016.

[28] A. A. I. A. Atu Dewi, "Potensi hukum adat: peran majelis desa pakraman (mdp ) bali dalam pembangunan hukum nasional," Kertha Patrika, 2016, doi: 10.24843/kp.2016.v38.i03.p05.

[29] B. A. Tegar Prabawa, "Peran Komunikasi Hindu Terhadap Perilaku Pemuda Yang Ajeg Bali di Tengah Pusaran Globalisasi," Ganaya J. Ilmu Sos. dan Hum., 2020, doi: 10.37329/ganaya.v3i1.425.

[30] I. K. D. P. Putra dan I. G. W. M. Yasa, "Efektivitas dan Dampak Revitalisasi Pasar Tradisional terhadap Jumlah Kunjungan, Pendapatan Pedagang, dan Pendapatan Pasar di Kota Denpasar," EJurnal EP Unud, 2017.

[31] N. M. A. Widiastini, I. W. Ardika, dan I. G. Mudana, "A Defense of Local People Working as Souvenir Vendors and Its Relation with the Female Identity in Kintamani Tourism Area, Bali," J. Hum., vol. 30, no. 2, hal. 109, 2018, doi: 10.22146/jh.v30i2.32196.

[32] E. Papastefanaki, “'The Mountain Education' -A Special Page in the Educational History of Greece," Rev. Hist. Polit. Sci., vol. 4, no. 2, hal. 35-42, 2016, doi: 10.15640/rhps.v4n2a4. 